\title{
Research on Consistency of Power Li-ion Batteries Storage
}

\author{
Hong-Wei WANG ${ }^{1, a,{ }^{*}}$, Zi-Qiang TAO ${ }^{1, b}$, Jun LIU ${ }^{2, c}$, Yan-Ling $\mathrm{FU}^{1, \mathrm{~d}}$, Nian-Peng \\ $\mathrm{SI}^{1, \mathrm{e}}$ and Hai-Qing XIAO ${ }^{1, \mathrm{f}}$ \\ ${ }^{1}$ Institute of Industrial and Consumer Product Safety, Chinese Academy of Inspection and \\ Quarantine, Beijing, China \\ ${ }^{2}$ Beijing Petrochemical Engineering Co., Ltd., Beijing, China \\ ${ }^{3}$ Inspection \& Quarantine Technology Center of Guangdong Entry-Exit Inspection \& Quarantine \\ Bureau of P. R. China \\ awanghongwei-1978@163.com, ${ }^{b}$ tzq@caiq.gov.cn, ${ }^{c}$ liujun@caiq.gov.cn, ${ }^{d} F y l 2 @ c a i q . g o v . c n,{ }^{e}$ snp \\ @caiq.gov.cn, ${ }^{\mathrm{f}} \mathrm{xhq123@caiq.gov.cn}$
}

Keywords: Power Li-ion batteries, Consistency, Safety.

\begin{abstract}
The consistency of power Li-ion batteries storage was researched at $20^{\circ} \mathrm{C}$ and $40^{\circ} \mathrm{C}$ environment temperatures. The results showed that the self-discharge rate of monomers of similar initial performance in storage will lead to inconsistency of monomer battery voltage after storage. That is to say, the battery self-discharge rate relates to the cathode materials, battery manufacturing process, electrolyte property and purity, temperature and storage time and other factors. And the difference of each monomer battery environment in the battery pack will inevitably exist based on the battery assembly design characteristics and operating environment characteristics.
\end{abstract}

\section{Introduction}

The research and development of electric vehicles is considered the most effective and most realistic ways currently to solve the world energy crisis and global environmental pollution. And the battery for electric vehicles is very important. The power Li-ion batteries with high specific energy, high specific power, long service life, wide operating range and other characteristics, has been successfully used in electric vehicles. Therefore, the consistency of power Li-ion batteries storage was researched at $20^{\circ} \mathrm{C}$ and $40^{\circ} \mathrm{C}$ environment temperatures in this paper.

\section{The Consistency Tests}

\section{Test Sample.}

The model and the parameters of cell in this paper as follows:

1) The model: domestic battery, rated voltage $3.7 \mathrm{~V}$, rated capacity $10 \mathrm{Ah}$, internal resistance $<6$ $\mathrm{m} \Omega$, weight $<320 \mathrm{~g}$

2) Dimensions: $133 \mathrm{~mm} \times 66 \mathrm{~mm} \times 18 \mathrm{~mm}$.

3) The composing of the battery: the cathode material is $\mathrm{LiMn}_{2} \mathrm{O}_{4}$, the anode material is graphite, the electrolyte is $\mathrm{LiPF}_{6}, \mathrm{EC}$ and DMC, and battery separator is celgard 2325.

\section{Test Instrument.}

Integrated battery tester, model Xin Wei TC53 High-precision battery performance test systems. Thermostat box, model SPHH-101; the test is shown in Fig. 1.

\section{Test Method.}

The method of consistency tests in this paper as follows:

1) The charge and discharge tests were carried out, and every cell voltage was monitored.

2) The SOC100\% battery was put in the thermostat box which temperature is set $20^{\circ} \mathrm{C}$ and $40^{\circ} \mathrm{C}$, and was laid aside for 5 days. 


\section{Results and Discussion}

The self-discharge accelerating experiment by placing the battery at $40^{\circ} \mathrm{C}$ was conducted. Select a batch of samples of basically consistent initial performance before storage, store them for 5 days and record the voltage changes daily. The initial state of monomer batteries and the battery state after 5-day storage monomer batteries as shown in Table 1 and Table 2, and the voltage changes of monomer batteries in the storage period are as shown in Figure 2.

The self-discharge refers to the natural loss of capacity when the battery is in storage, reflecting by open-circuit voltage drop after a period of storage. According to Table 1, Table 2 and fig. 2, the self-discharge rate of monomers of similar initial performance in storage will lead to inconsistency of monomer battery voltage after storage. In a word, the battery self-discharge rate relates to the cathode materials, battery manufacturing process, electrolyte property and purity, temperature and storage time and other factors.

According to the battery assembly design characteristics and operating environment characteristics, the difference of each monomer battery environment in the battery pack will inevitably exist. For example, in square lithium-ion battery pack, the ambient temperature of the batteries in the middle and the surrounding batteries, and the stress condition of the battery are different from each other (Fig. 3). The most significant factor is the temperature difference, if the active thermal balance and thermal management are not used, the temperature of batteries in the middle is often $5-15^{\circ} \mathrm{C}$ higher than that of the surrounding batteries, even the temperature difference is much higher, at this moment, the battery charge rate, aging speed and other characteristics have been changed fundamentally, thus lead to battery decay rate difference becoming larger, and further accelerate the termination of system service life.

\section{Summary}

Based on the foregoing test results, analysis and discussions, the conclusion can be obtained as follows: 1) the self-discharge rate of monomers of similar initial performance in storage will lead to inconsistency of monomer battery voltage after storage. That is to say, the battery self-discharge rate relates to the cathode materials, battery manufacturing process, electrolyte property and purity, temperature and storage time and other factors. 2) According to the battery assembly design characteristics and operating environment characteristics, the difference of each monomer battery environment in the battery pack will inevitably exist.

\section{Acknowledgement}

The authors would like to acknowledge the financial support provided for this research work by Fund: Fundamental scientific research projects of Chinese Academy of Inspection and Quarantine (CAIQ) No. 2017JK024.

\section{References}

[1] GB/Z18333.1-2001 Lithium-ion batteries for electric road vehicles (2001)

[2] QCT 743-2006 Lithium-ion Batteries for electric vehicles. National Development and Reform Commission, 2006.

[3] IEC 62133: 2002, Secondary cells and batteries containing alkaline or other non-acid electrolytes-Safety requirements for portable sealed secondary cells, and for batteries made from them, for use in portable applications. 2002.

[4] IEC 62660-2-2010, Secondary lithium-ion cells for the propulsion of electric road vehicles - Part 2: Reliability and abuse testing. 2010.

[5] UL 2580-2011, Standards for batteries of use in EV. 2011. 
Table 1 initial state of monomer batteries

\begin{tabular}{|l|l|l|l|l|l|}
\hline & $\mathrm{S} 101$ & $\mathrm{~S} 102$ & $\mathrm{~S} 103$ & $\mathrm{~S} 104$ & $\mathrm{~S} 105$ \\
\hline voltage $/ \mathrm{V}$ & 4.20 & 4.20 & 4.19 & 4.19 & 4.19 \\
\hline $\begin{array}{l}\text { Internal } \\
\text { resistance } / \mathrm{m} \Omega\end{array}$ & 5.90 & 5.98 & 5.97 & 6.09 & 6.13 \\
\hline
\end{tabular}

Table 2 the battery state after 5-day storage monomer batteries

\begin{tabular}{|l|l|l|l|l|l|}
\hline & $\mathrm{S} 101$ & $\mathrm{~S} 102$ & $\mathrm{~S} 103$ & $\mathrm{~S} 104$ & $\mathrm{~S} 105$ \\
\hline voltage $/ \mathrm{V}$ & 4.18 & 3.19 & 3.39 & 3.20 & 3.95 \\
\hline $\begin{array}{l}\text { Internal } \\
\text { resistance } / \mathrm{m} \Omega\end{array}$ & 5.89 & 6.13 & 6.01 & 6.00 & 5.78 \\
\hline
\end{tabular}

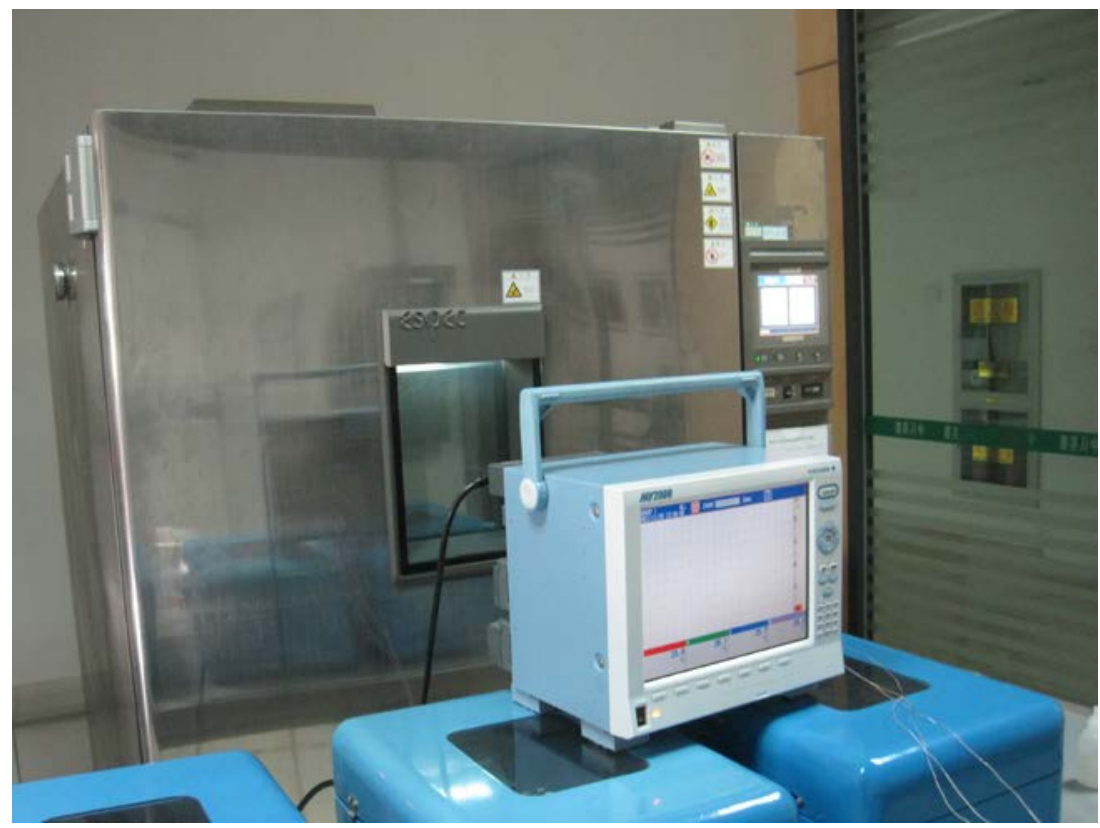

Fig.1 The consistency tests

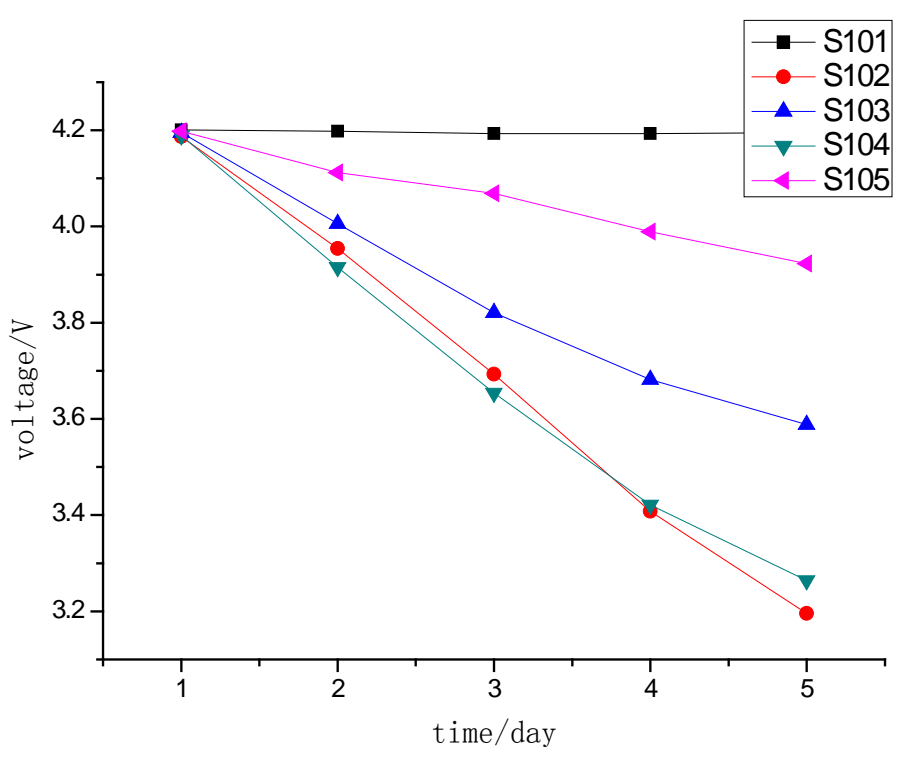

Fig. 2 voltage changes of monomer batteries in the storage period 


\begin{tabular}{|c|c|c|c|c|c|c|c|c|c|c|c|c|c|c|c|}
\hline+ & - & + & - & + & - & + & - & + & - & + & - & + & - & + & - \\
\hline+ & - & + & - & + & - & + & - & + & - & + & - & + & - & + & $\overline{-}$ \\
\hline+ & - & + & - & + & - & + & 7 & + & - & + & -7 & + & - & + & $=$ \\
\hline+ & $=$ & + & - & + & - & + & - & + & - & + & - & + & - & + & $=$ \\
\hline+ & - & + & - & + & - & + & - & + & - & + & - & + & - & + & - \\
\hline+ & - & + & - & + & - & + & - & + & - & + & - & + & - & + & $=$ \\
\hline
\end{tabular}

Fig. 3 the diagram of battery assembly 